\title{
Leveraging Corporate Social Responsibility for the Advancement of Development Goals in India: Sanitation and Cleanliness Movement in India
}

\author{
Beena D. Lawania ${ }^{1}$ and Shikha Kapoor ${ }^{2}$
}

\begin{abstract}
CSR is a potent tool in achieving the social and environmental goals of a nation by collaborating partnership with corporations in combating developmental challenges in emerging economies like India. The State Government in India can provide big leap to government developmental programs if they can muster wholehearted support from corporates for implementing social welfare and awareness programmes. This paper makes a special reference to the Cleanliness drive "Swachh Bharat Abhiyan (SBA)", wherein Indian Government identified that the ambit of SBA is vast and utilized the funds and expertise of corporate through CSR to collaborate in implementing programmes such as the construction of toilets, sewage treatment, river cleaning and so forth. This paper is analytical and descriptive in explaining how government and corporates together can shape social demographics of India through CSR by leveraging the value and resources of corporate and utilizing the governmental expertise in identifying the social gaps and accordingly formulating the plans for development to create high impact outcomes. The purpose of this paper is to investigate the role of CSR in the government development plan in India. It explores the intersection of corporate social responsibility efforts and public policy. This qualitative research is based on extant literature on CSR and detailed interviews with government and agencies like NGOs, social enterprises which are involved at the level of identifying corporate partners and implementing social campaigns.
\end{abstract}

JEL Classification: M14, M48, N15, O38.

Keywords: CSR, SBA, development goals, India.

\footnotetext{
${ }^{1}$ Amity University, India.

${ }^{2}$ Amity University, India.
} 


\section{INTRODUCTION}

India, in the backdrop of a grim social condition and being a signatory to United Nation Global Compact popularly known as Sustainable Development Goals(SDGs), had to develop a plan to achieve 17 SDGs and their targets. Indian government rolled out the legislation related to CSR spent to achieve these ambitious targets and also to regularise the CSR for significant social and environmental outcome. While in recent times there has been a shift in companies' focus from just economic goals to social good worldwide and hence shown their participation and investment in various social programmes like education, health, awareness campaigns and skill development programmes that have a potential of bringing impact in the society. This change is understandable as these companies have realised how irresponsible and unethical practices can negatively impact their brand image and bear a risk of losing consumer trust and loyalty (Chaudhary, 2007) while at the same time Government being the important agent in the external business environment can influence the business conduct for the benefit all the stakeholders most importantly the community (Gayle and Allard, 2008) like India enforced the statute for CSR regulation in the year 2013. Emerging economies like India have to collaborate with corporates to upgrade its socio-economic parameters and environmental indicators to transform into a progressive and developed nation. (Chatterjee, 2017).

This paper explores the utility of CSR and its governance for one specific socioenvironmental parameter in India i.e. sanitation in urban and rural India (SDGs no. 6: clean water and sanitation). The Indian government has mobilised the mass, government bodies, and corporates for sanitation drive which is called Swachh Bharat Abhiyan in Hindi. The Indian government has identified corporates and Public Sector Undertakings and the civil society as the crucial link in executing and facilitating this development goal. Therefore companies are engaging themselves in the process of social responsibility by taking up or collaborating in government development projects related to health, education, and the environment by utilizing the available resources and by encouraging and supporting social innovation (Pradhan, 2010; Sarkar, 2015). CSR in India is evolving from sporadic philanthropy to strategic alignment of CSR with business process and ethics for balancing companies' economic, environmental and social goals (Global CSR Summit 2013: An Agenda for Inclusive Growth by EY and PHD Chamber of Commerce). This evolution of CSR cannot be explained in the exclusion of government role and its intent to improve the outcomes of companies' CSR. The larger good of society and improvement of provision of various facilities and dispersion of outcomes call for integration of efforts of companies and government.

To understand the above mentioned scenario of governmental and corporate collaboration to tackle the social problem of sanitation and how the government has provisioned the CSR spent and utilise the fund under CSR to improvise the condition of sanitation in urban, rural and schools of India, the paper is presented in different sections starting with Introduction and CSR overview in the emerging economies as we are discussing specific problem present in developing nations (here India) followed by discussion about government's role in CSR Agenda and review of literature. There are four objectives related to government, corporates and Swachh Bharat Abhiyan which will be dealt with available reports-government and private and a complete account of two agencies (government and corporate) collaborating for sanitation drive is presented. 


\section{OVERVIEW AND PERSPECTIVE OF CSR IN EMERGING ECONOMIES}

The concept of corporate social responsibility (CSR) aims both to examine the role of business in society and to maximise the positive societal outcomes of business activity. United Nation (Sustainable Development Innovation Briefs February 2007).

The above lines make it clear that CSR covers the whole range of responsibility towards society in general with specific outcomes which will benefit society and eventually benefit the development goals of developing nations like India. CSR is an overall contribution of business to the inclusive and sustainable development. The policymakers in middle-and-lowincome countries have directly sought to involve business and corporations in meeting social challenges. India, the biggest democracy and second largest populated country which is inflicted with many social challenges and dilemmas, has issued guidelines for its public sector to spend stipulated amount on CSR and make necessary disclosures.

India's prominent place in the world as the one of the fastest growing economy (World Economic Outlook Update 2017) is definitely due to the gain in business activity while at the same time India's social and human index is challenging and calls for concerted efforts of government and corporates by creating better opportunities for weaker sections and leveraging corporate resources, technology, and know-how to create social value and ultimately shared prosperity (Chatterjee, 2017) (Raghunath, 2017)During the last two decades, there has been a noticeable change in the conduct of business towards social and environment responsibilities realising that CSR is a social licence to conduct business and community is the one of the important stakeholders hence companies with social and environment outlook have mutual beneficial existence. (Raghunath, 2017). Owing to the changing market situation, Companies have shifted their focus from pure economic focus and sporadic philanthropy to three important factors viz. But nowadays with the changing market situation, this focus is shifting and including three other factors: environmental, educational and health responsibilities. Companies or organizations have started spending their social responsibility money for environmental benefits, public health care initiatives and for providing free education to the wards of employees and underprivileged. To understand the above perspective it is needed to define the CSR as it is a little difficult to place one concrete idea through a definition.

In view of this paper's requirement, few rationale thoughts can be presented in the given manner: ---

1. Developing countries have a plethora of social challenges and environmental issues to address. The government can see CSR as an important means to achieve the development goals.

2. India is a signatory to UN SDGs and hence a positive and constructive method for achieving these goals is the concerted efforts of Government and Corporates by utilizing the CSR corpus for national agenda.

3. Private and public sector can leverage its strength to create opportunities which should be broad-based and can directly involve itself in the development efforts while government can passionately bring up the issues and use its machinery for identification of the beneficiaries and framing the programmes with defined outcomes. 


\section{Potential Role of government in CSR Agenda}

The government, in developing countries, is the authority and agency to identify social gaps and environmental compliances; formulate social programmes and objectives to fill such gaps; understand the role of companies in facilitating execution and awareness; communication of objectives to government agencies and companies to define their role in such government developmental goals. In India, social gaps as for the availability of basic services is huge in the contrast of class, region, rural-urban divide and economic factors. Much debate was built around the obligation of corporates and socio-economic and environmental impact of the business activity and how voluntary CSR effort of the organizations to operate in a sustainable manner can bridge such social gaps. Due to compelling reasons and challenges, the Indian government has approved the India centric agenda for CSR to address the problems like poverty alleviation, gender equality, education, environmental conservation, livelihood etc.

India stands out as the only country in the world to have championed the idea of a compulsory fixed percentage of annual CSR spend with the addition of section 135 and schedule VII in The Companies Act 2013. Section 135 of the act says any company that has a net worth of 100 million US \$ or a net profit of 1 million US \$ during any financial year shall constitute a CSR committee of the Board consisting of three or more directors out of which one director shall be independent. India has clearly mandated the corporate to form the committee for policy making and planning the execution, take up the CSR plan in programme and project mode with clear measurable outcomes, making a CSR corpus of at least $2 \%$ of $\mathrm{PBT}^{*}$ and make provision for reporting of such spent in the public domain. It is indicated that any project or plan that is in pursuance of its normal course of business shall not be constituted as CSR activity.

The partnership of corporate and implementing agencies for proper execution of CSR projects can go long way in bringing desired changes in the social indicators for better tomorrow.

\section{Swachh Bharat Abhiyan}

Undoubtedly, sanitation stands as one of the national priorities as it has been enshrined as UN SDGs and also India's 60\% population doesn't have access to clean sanitation. The Swachh Bharat Program is devised to tackle this problem at the war footing level to free India from open defecation by 2020. It is a movement to provide comprehensive sanitation planning, behavioural changes in people and explore private partnership in the goal accomplishment and rehabilitate manual scavengers. On 9th June 2014, the President of India in his joint address to both the Houses of Parliament said that homes without availability of toilets and public places in our country are littered with garbage is a social menace and hence Swachh Bharat Mission, a movement with the goal to ensure hygiene, waste management, and clean sanitation, will be launched to pay tribute to Mahatma Gandhi on his 150th birth anniversary to be celebrated in the year 2019. Therefore the Indian Government identified a private partnership for its involvement in building the Swachh Bharat Fund and various models like OPEX, operation and maintenance and CAPEX, capital expenditure and were to be explored for a successful partnership in the creation of facilities and infrastructure for the movement called for Clean India drive.

To improve the sanitation facilities, seven key mission objectives have been identified. They are: (1) open defecation elimination; (2) manual scavenging eradicating; (3) scientific solid 
waste management; (4) to bring behavioural changes related to healthy sanitation; (5) awareness about sanitation and public health dissemination ; (6) capacity building of urban local bodies (ULBs); and (7) to promote private participation in CAPEX (capital expenditure) and OPEX (operation and maintenance) model.

Why is SBA a development agenda? According to World Bank reports, non-availability of sanitation infrastructure and poor hygiene have impacted India's GDP amounting to an annual economic loss of approximately 6.4 percent in 2014.SBA is a step forward to contain the social and behavioral problem, of open defecation, which is capable of affecting business and economy too. Hence corporates also need to intervene and act to leverage their strengths be it finances, goods/products or services for the benefit of society and the environment. Watchdogs like UN and other international forums like R.I.C.E. have reported the gravity of the issue of open defecation which stands at $60 \%$ of the Indian population have no access to clean sanitation or practices open defecation (Ghosh, 2015). Access to clean sanitation, to maintain high hygiene, is the agenda of this decade in the developing nations to elevate the sanitation profile and be able to maintain good hygiene for better health and opportunity.

How can CSR provide thrust to SBA in India? India has brought a huge amount of CSR fund from its prosperous private and public companies into the foray of the development sector. This mandated CSR amount as disclosed by the government stands to the tune of Rs 1.39 billion in the year 2014-15 (CSR data from csr.gov.in).This can be construed that CSR mandate in India has provided a buzz in the development sector and companies to use this money for social welfare and the projects that eventually will support the national agenda.

\section{SOCIAL DEMOGRAPHICS}

Kingsley Davis developed the term "social demography" in a 1963 paper (Heer 2005). Social issues came to be viewed as problems that could be solved scientifically. Social demography emerged as a prime tool to isolate, explain, and predict factors influencing social issues (Tim Chatterton and Charlie Wilson, 2013) such as behavioural aspects of people regarding cleanliness in different segments of society like open defecation in rural India. The demography of social group classification of people who fall into the category of impoverished can mainly be divided into urban and rural in India. The Swachh Bharat Mission has two components i.e. rural and urban components - Swachh Bharat Mission (Urban) and Swachh Bharat Mission (Gramin) ${ }^{2}$. Ministry of Urban Development (MoUD) is in charge of the Swachh Bharat Mission (Urban) and Ministry of Drinking Water and Sanitation (MDWS) is in charge of Swachh Bharat Mission (Gramin) and the overall mission is coordinated by MDWS. The Swachh Bharat Mission (Gramin) aims to (i) elimination of open defecation and promotion of cleanliness and hygiene (ii) sanitation coverage in rural areas (iii) Role of Panchayati $\mathrm{Raj}^{3}$ Institutions in motivating communities to adopt sustainable sanitation practices and facilities through massive awareness creation and dissemination of health education (iv) encourage cost effective and appropriate technologies for ecologically safe and sustainable sanitation and (v) develop wherever required, community managed sanitation systems focusing on scientific solid and liquid waste management systems for overall cleanliness in the rural areas. The components of the mission are the construction of individual household toilets and community sanitary complexes; Information, Education, and Communication (IEC); start-up activity and capacity building; and solid and liquid waste management activities in Gram Panchayats. The Swachh Bharat Mission (SBM) consists of

\footnotetext{
${ }^{3}$ Panchayati Raj is the local government at the village level in India
} 
components for providing individual household toilets, community and public toilets and scientific waste management. The government development programmes have to be formulated on the basis of social demography which will give a clear picture of social gaps and accordingly remedial measures can be formulated.

In order to isolate the problems on the basis of demographic variables, the following are the important points to consider

1. In contrast to 88.8 percent of urban households having access to clean sanitation, only 45.3 percent of households in rural areas have access to sanitary toilets. Hence there was a compelling requirement of the huge fund for the construction of toilets.CSR corporates and PSUs can provide a big impetus to this drive. Further, in the study, it is supported by the data available and reports that CSR has contributed to meet this goal of $100 \%$ clean sanitation.

2. Behaviour change is a key issue of the Swachh Bharat Abhiyan as sanitation is not only an infrastructural issue but a behavioural issue too. Effective sanitation and hygiene programmes need to jointly intervene to change behavioural aspect related to usage of toilets with the selection of the right technology. Changing behaviour requires culturally sensitive and appropriate health education (WHO 2004; Rocio Florez, 2013).

3. Of the 86 companies that published disclosures about CSR spent on geographical coverage, $52 \%$ were focused exclusively on rural areas, compared to only $17 \%$ which focused on urban areas (CSR in WASH, 2015).

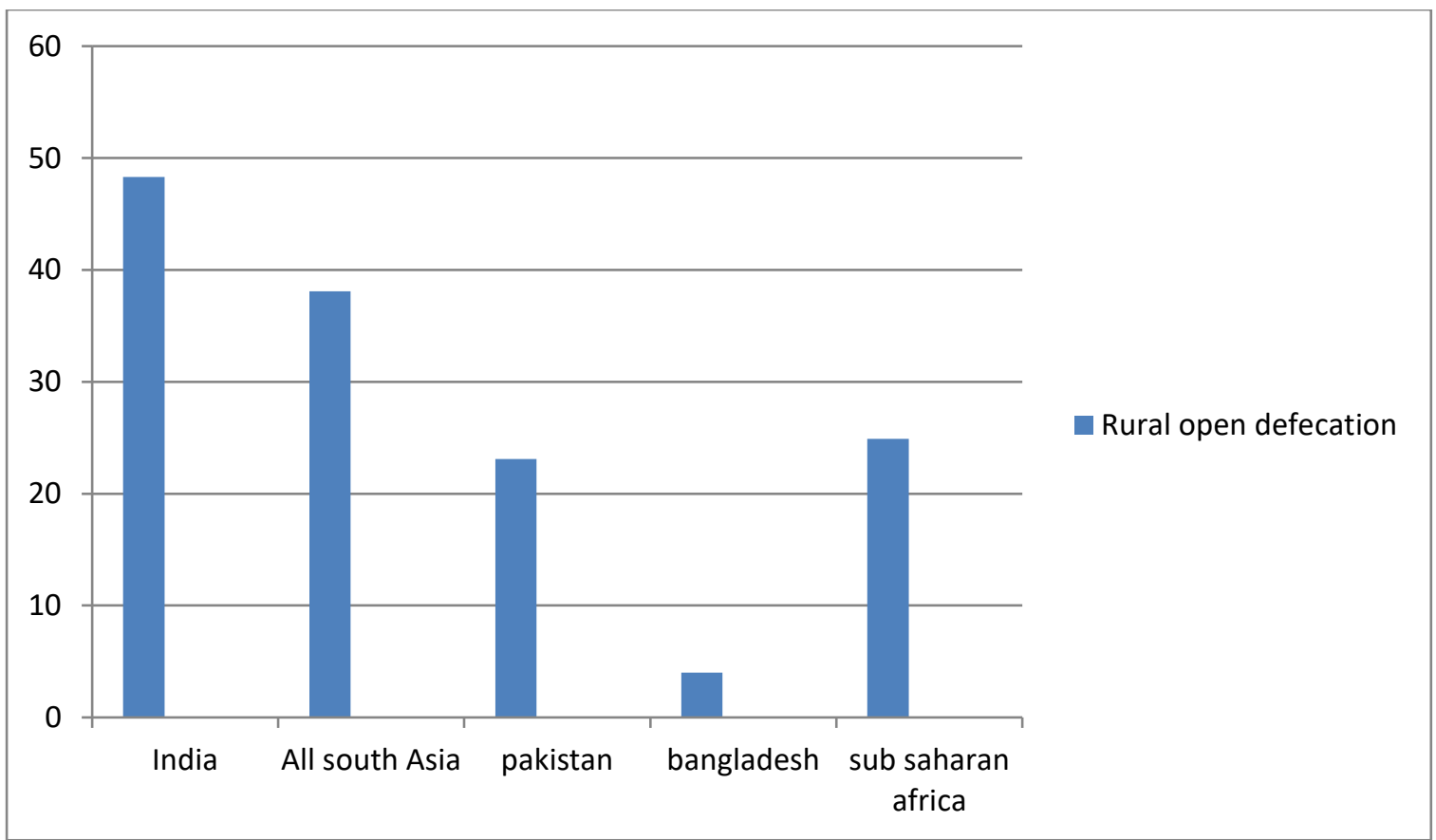

Source: R.I.C.E

\section{Graph1.1 International Comparison of Open Defecation (2012)}

The government of India has isolated the issues of materiality, in this Mission, on the basis of demographic variables and used such variables in policy matter to tackle the problem scientifically. The mission is divided into rural and urban components. 


\section{REVIEW OF LITERATURE}

CSR has emerged as no man's child with its variety of definitions and interpretations and while Freeman has enjoined the concept of CSR with the debate that companies are instrument of public policy and hence their responsibility for various stakeholders is pronounced and utility of CSR for the support of disadvantaged group (R. Edward Freeman, 1984 and 2009), with a reference to Chester Barnard's (1938) -inducement contributionll framework, presented a more positive view of managers' support of CSR. According to this view, it is highly imperative to focus on the non-financial stakeholders for the greater good of the society as an important beneficiary and engage them in CSR because in case of failure of such engagement companies may lose the support of the community and other non-financial stakeholders. The Stakeholder theory was further developed by Donaldson and Preston (1995) who stressed the moral and ethical dimensions of CSR, as well as the business case for engaging in such activity. Nowadays, more and more researchers and authors focused on the stakeholder approach in the development of the business responsibility theories (Cohen 2010), (Homes and Watts, 2000) emphasized stakeholders' engagement as "the essence of CSR".

A survey by TERI Europe and ORG-MARG (2001) in several cities in India exhibit that more than $60 \%$ of the surveyed people felt that the business houses should take the responsibility of bridging the existing gap between rich and poor, reducing human rights abuses, looking into social problems and enhancing economic stabilities. Similarly a survey by Partners In Change (PIC) named "Corporate involvement in social development in India" and joint survey by the British Council, UNDP, Confederation of Indian Industries and Price Water house Coopers "Corporate Social Responsibility Survey, 2002, India" have also highlighted the emerging corporate participation in the CSR process. The findings of these surveys emphasized companies across India reveal that philanthropy is the most significant driver of CSR, followed by image building, employee morale, and ethics respectively. Moon (2002b) argues that Business Responsibility is a non-profit community involved exercise which calls for a voluntary contribution of finance, goods, and services to the community or a governmental cause. (Moon, 2002) This is often in the form of social partnerships with nonprofit and for-profit organizations.

In 2003, Molly Attenborough and James Shyne conducted a study named CSR, public policy and the Oil Industry in Angola on ten major oil companies currently operating in Angola. The study explores the role of public sector in strengthening CSR. It prompted a detailed analysis of CSR investment as a business value and its impact upon targeted beneficiaries. The study also describes the importance of the public sector in carrying out the CSR activities and focusing on the participation of potential public section that would make corporate efforts impactful for the beneficiaries and companies both. It was found that the representatives of ten oil companies were familiar with the issues of CSR and they were ready to recognize the importance of the ethical and practical imperative of CSR for their companies to operate in a socially responsible and environmentally sustainable manner.

McGaw (2005), cites the development of leaders for a global society based on sustainability as a major challenge in the implementation of CSR and it is the responsibility of corporates to enhance the leadership capabilities of individuals for real change to see the business responsibility index (Alessia D'Amato,2009). According to this author, the task and challenge will be to develop leaders for a sustainable global society by encouraging imagination and the accomplishment of a positive change. Harish Kumar (2012) in his research article entitled 
"CSR Revisited" has thrown lights on four different approaches of companies towards CSR viz; Good Governance, Ruinous CSR, Discretionary CSR, and Illusion CSR. He also tried to highlight the argument against the CSR as well as the CSR driver. The researcher also found eight companies towards CSR viz; Good Governance, Ruinous CSR, Discretionary CSR, and Illusion CSR. He also tried to highlight the argument against the CSR as well as the CSR driver. The researcher also found eight factors that drive the CSR initiatives. They are Philanthropic Attitude, Governmental Actions, Environmental Concern, Ethical Consumerism, Crises and Calamities, Globalization and Market force, Social Awareness and Education, and Social Expectation. It is understood that government plans to change the sanitation face of India cannot be thought of without an active participation of private sectors, stakeholders, and community. This study is exploring the role of Private companies and PSUs in understanding the social gaps and participating in government intent to change the society. Following objectives will be extensively explored in the study on the basis of available reports and literature and annual reports and disclosure of the companies:

To present an analysis of the areas of active cooperation of corporations PSU / Private business houses in the proper execution of the development plan. This objective of the study is in reference to Swachh Bharat Abhiyan and the partnership of private and public corporations for the developmental goals of SBA.

2. To present the entire stakeholder spectrum for the development project and identification of key stakeholders to engage them in a most appropriate manner by finding material issues.

3. To analyse the CSR allocation of funds to build the social infrastructure

4. To recommend robust institutional mechanisms for effective utilisation of CSR fund and directing CSR activities for the creation of social infrastructure

\section{METHODOLOGY}

Data and information used in this qualitative paper were acquired from different information sources viz. international and national journal articles and reports, government reports, webbased statistics, and fact sheets. Information is gathered through extensive online search and analysed to understand the scope leveraging CSR for financing and constructing social infrastructure for development goal.

\section{THE PRESENT STUDY}

Objective 1. To present an analysis of the areas of active cooperation of corporations PSU / Private business houses in the proper development of cities and town. This objective of the study is in reference to Swachh Bharat Abhiyan and the partnership of private and public corporations for the developmental goals of SBA.

The Indian government has called for active participation from business entities through their CSR window to engage themselves at various levels of execution of SBA. The is believed that effective partnerships between foundations, industry, NGOs and the government will place India's social development on a fast track. The President of India and governors of States have urged the companies to show their responsibility towards society and work towards this mammoth task of providing India a clean sanitation and spread the awareness amongst their stakeholders. 
Table 1.1 Participation of companies in SBA

\begin{tabular}{|c|c|c|}
\hline $\begin{array}{l}\text { Provision Of Private } \\
\text { Participation In SBA } \\
\text { Swachh Bharat Kosh (SBK) } \\
\text { (Sanitation Fund) to attract CSR } \\
\text { funds from the corporate sector. }\end{array}$ & $\begin{array}{l}\text { Private companies } \\
\text { participation } \\
\text { Private companies and PSUs } \\
\text { donated CSR amount to SBK }\end{array}$ & $\begin{array}{l}\text { Outcome } \\
\text { Total fund mobilized under } \\
\text { Swachh Bharat Kosh }(\mathrm{SBK})^{\mathrm{ii}} \text { as } \\
\text { by November } 2017 \text { stood at Rs } \\
600 \text { crore in the last three years } \\
\text { as informed by concerned } \\
\text { Minister. }\end{array}$ \\
\hline Construction of toilets & $\begin{array}{l}\text { The inclusion of multiple } \\
\text { agencies for construction of } \\
\text { toilets (one of the important } \\
\text { CSR agenda.) }\end{array}$ & $\begin{array}{l}8.64 \text { lakh toilets were built in } \\
\text { rural areas and } 10.63 \text { lakh toilets } \\
\text { were constructed in urban areas } \\
\text { (Swachhta Status Report } 2016 \text { ) }\end{array}$ \\
\hline Capacity building & $\begin{array}{l}\text { Engagement of various agencies } \\
\text { and companies employees to } \\
\text { develop the right mix of skills, } \\
\text { knowledge, and experience to } \\
\text { facilitate, finance, manage and } \\
\text { monitor water, sanitation and } \\
\text { hygiene programmes in society } \\
\text { effectively. }\end{array}$ & $\begin{array}{l}\text { 1) Dissemination of information } \\
\text { both at the rural and urban level } \\
\text { for efficient waste management } \\
\text { system and rural toilet } \\
\text { infrastructure. 2) World Toilet } \\
\text { Organization, Sulabh } \\
\text { International, Gramalaya etc. } \\
\text { contracted for providing training } \\
\text { to these people. 3) Upgrading } \\
\text { and maintenance of dilapidated } \\
\text { toilets. }\end{array}$ \\
\hline $\begin{array}{l}\text { Innovation in toilets based on } \\
\text { sustainable model(Social } \\
\text { entrepreneurs and innovators) }\end{array}$ & Private companies like A2Z, & $\begin{array}{l}\text { 1) Eco-friendly toilets 2) Solar } \\
\text { powered toilets 3) Waste } \\
\text { management system 4) Low- } \\
\text { cost technology }\end{array}$ \\
\hline
\end{tabular}




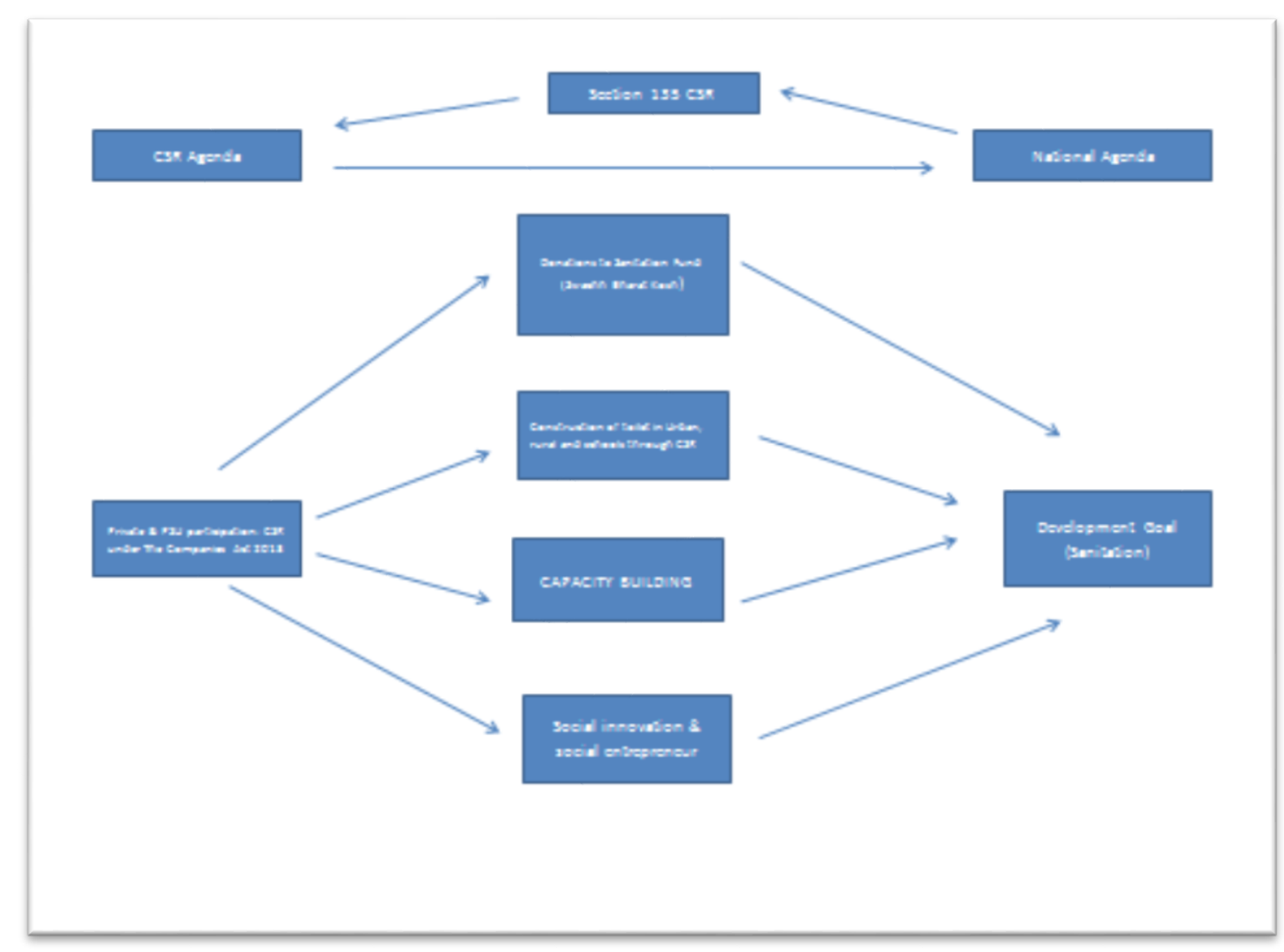

\section{Chart 1. Collaborative platform between government and private for development agenda (SBA here) Adapted from Chatterjee Model for CSR and national agenda}

Objective 2. To present the entire stakeholder spectrum for the development project and identification of key stakeholders to engage them in a most appropriate manner by finding material issues.

The most appropriate manner is to bring voluntary engagement of companies in SBA movement. India is the world leader in CSR legislation by adding section 135 in The Companies Act 2013 which mandated the first formal engagement of the corporate sector and enshrined the process of responsible governance through CSR into law. The government called upon the whole corporate society to bring forth their hand to support SBA wholeheartedly. The government knew it very well that such a social gap which demands huge funds, technological support, and innovation, capacity building and stipulated behavioural changes couldn't be filled without the involvement of all stakeholders.

The government identified the stakeholders in the process SBA goals:

1. Parliamentarians and state government
a) Ministry of Urban Development
b) Ministry of Drinking Water and Sanitation (MDWS)
c) Ministry of HRD and
d) Other central government Ministry
e) State Government
i. District office
ii. Municipality/municipal corporations
iii. Gram panchayats 
2. NGOs, Civil Society, Foundations and Section 8 Companies

3. Private Companies and PSUs

4. Fund providers like Companies, World Bank

5. Communities

Table 1.2 stakeholder perspective in SBA to bring a concerted effort

\begin{tabular}{|c|c|c|}
\hline Broad Category & Sub category & Individuals/groups \\
\hline \multirow{7}{*}{$\begin{array}{l}\text { Those who can affect the } \\
\text { project SBA }\end{array}$} & \multirow{4}{*}{$\begin{array}{l}\text { Those involved in the delivery } \\
\text { of the project }\end{array}$} & Social entrepreneurs \\
\hline & & Corporate foundations \\
\hline & & $\begin{array}{l}\text { NGOs } \\
\text { Civil Society } \\
\text { Gram Panchayat }\end{array}$ \\
\hline & & City Municipality \\
\hline & \multirow[t]{3}{*}{$\begin{array}{l}\text { Those who determine the } \\
\text { context }\end{array}$} & $\begin{array}{l}\text { Central Government } \\
\text { Departments like Niti Ayog, } \\
\text { Ministry of Urban } \\
\text { Development. }\end{array}$ \\
\hline & & $\begin{array}{l}\text { State Government } \\
\text { District Administration }\end{array}$ \\
\hline & & $\begin{array}{l}\text { Non-departmental public } \\
\text { bodies such as Environment } \\
\text { Agency, Housing Corporation } \\
\text { etc. }\end{array}$ \\
\hline $\begin{array}{l}\text { Those who are affected by the } \\
\text { project }\end{array}$ & Directly affected & $\begin{array}{l}\text { Communities } \\
\text { Specific demographic groups } \\
\text { such as those based on race, } \\
\text { ethnicity, gender, age etc. }\end{array}$ \\
\hline \multirow{2}{*}{\multicolumn{2}{|c|}{ Others who may be interested }} & $\begin{array}{l}\text { Environmental/social } \\
\text { campaigning organizations }\end{array}$ \\
\hline & & $\begin{array}{l}\text { Researchers/ Academics } \\
\text { Media }\end{array}$ \\
\hline
\end{tabular}


Lawania \& Kapoor | Leveraging Corporate Social Responsibility for the Advancement of Development Goals

Others who may be interested

Potential users/clients for future projects

Table 1.3 mechanisms to identify key issues ${ }^{4}$

Stakeholders \& their key issues in Development programme (specific to Swachh Bharat Abhiyan)

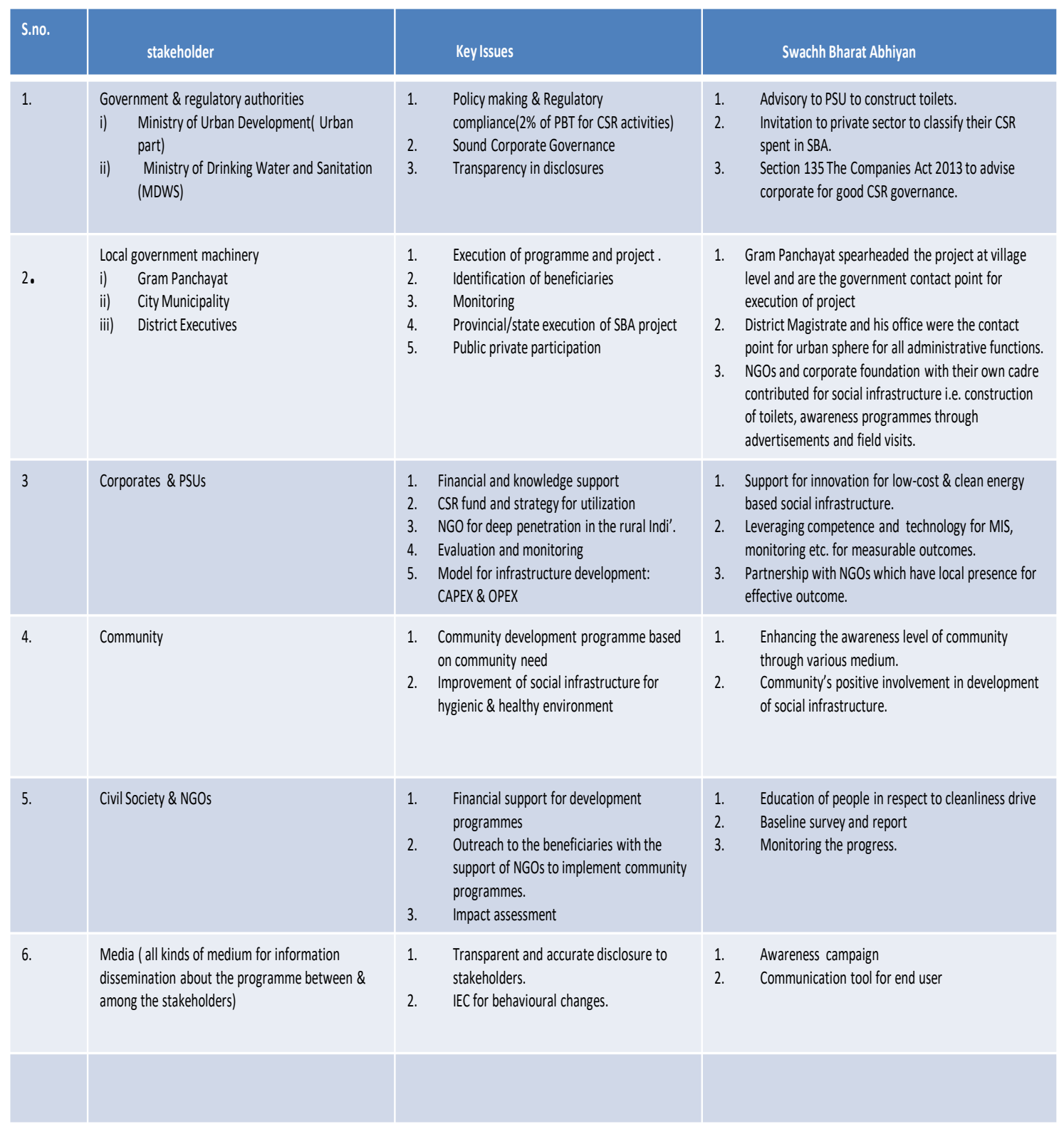

\footnotetext{
${ }^{4}$ authors own compilation based on ITC method of stakeholder consultancy
} 
Objective 3: To analyse the CSR allocation of funds to build the social infrastructure

The mission has obtained funding and support from the World Bank. Also, private companies and public sector undertakings as a part of CSR initiatives, and provincial governments under their two schemes Sarva Shiksha Abhiyan ${ }^{\text {iii }}$ and Rashtriya Madhyamik Shiksha Abhiyan has provided a huge fund for SBA. Identification of stakeholders facilitated the fund development for SBA goals. Cleanliness drive, which is the basic crux of Swachh Bharat Abhiyan (SBA), has been promoted in a manner where big corporations and PSUs are engaged in this programme in order to support/help with their funds, expertise and other stakeholders for the success of this ambitious programme. This accumulated fund is utilised to construct toilets in schools, rural and urban areas and hygiene awareness programmes to achieve the goal of cleanliness.

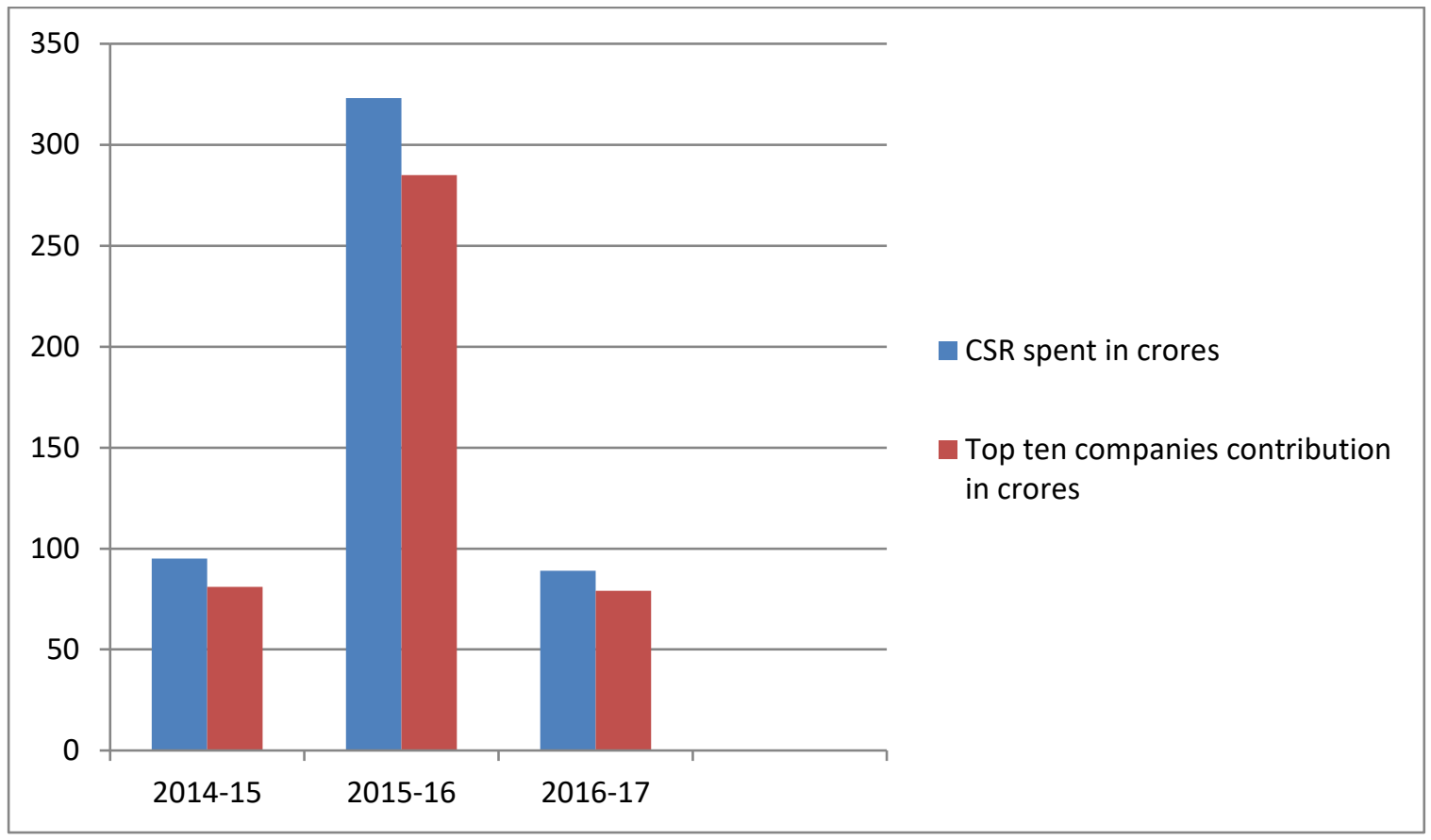

\section{India}

Graph 1.2. The contribution of companies(CSR contribution) to SBA in

The top 10 companies have contributed the major share in SBA and in the year 2015-16 there was a major contribution to the tune of 323 crore in SBA.

Objective 4. To recommend a robust institutional mechanism for effective utilisation of CSR fund and directing CSR activities for creation of social infrastructure

The government has clearly defined various agencies that can work together with other agencies or alone for the utilisation of CSR fund and corporate expertise to achieve developmental goals of Swachh Bharat Abhiyan. 


\section{Diagram 2. Institutional framework}

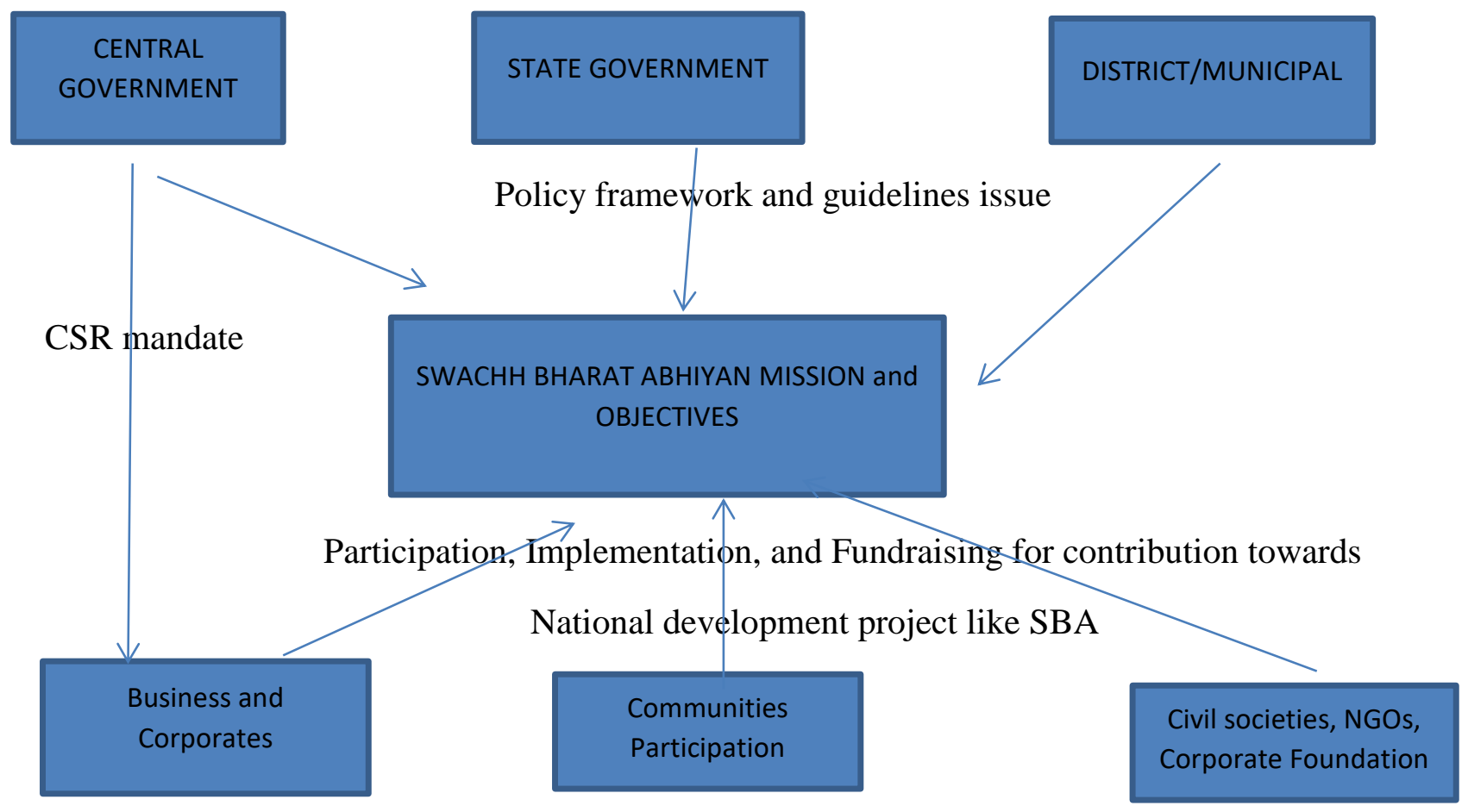

Under the Swachh Bharat Mission 1.04 crore household toilets are to be constructed across India. To complete this mammoth task an active participation of various Government as well as various business organizations, Non-governmental organizations are engaged in this mammoth task. The Ministry of Human Resource Development, Government of India launched 'Swachh Bharat Swach Vidyalaya' (SBSV) initiative in 2014 to ensure that all schools in India have access to separate functional toilets for boys and girls. The initiative also has its emphasis on promoting safe and appropriate hygiene practices in schools and behaviour among children.

An attempt has been made to study at length the Swachh Vidyalaya ${ }^{\mathrm{v}}$ and the national status is given hereunder: 
Table 1.3 Swachh Vidhalaya Construction Targets (Contribution of CSR and funds in toilet construction)

\begin{tabular}{|l|l|l|l|l|l|}
\hline $\begin{array}{l}\text { National } \\
\text { Summary }\end{array}$ & $\begin{array}{l}\text { Government } \\
\text { Funds (SSA } \\
\text { and RMSA }\end{array}$ & $\begin{array}{l}\text { Prii }) \\
\text { Corporates }\end{array}$ & $\begin{array}{l}\text { Public Sector } \\
\text { Undertakings }\end{array}$ & $\begin{array}{l}\text { Swachh } \\
\text { Bharat Kosh }\end{array}$ & Total no. \\
\hline $\begin{array}{l}\text { Approved/Booked } \\
\text { (no. of toilets } \\
\text { constructed in } \\
\text { schools) }\end{array}$ & 258,644 & 3,466 & $\mathbf{1 4 1 , 6 3 6}$ & $\mathbf{1 4 , 0 5 0}$ & 417,796 \\
\hline & $62 \%$ & $1 \%$ & $34 \%$ & $3 \%$ & 417,796 \\
\hline Work completed & $258,644(100 \%)$ & $3,466(100 \%)$ & $\mathbf{1 4 1 , 6 3 6 ( 1 0 0 \% )}$ & $\mathbf{1 4 , 0 5 0 ( 1 0 0 \% )}$ & nil \\
\hline Work in progress & nil & nil & nil & & \\
\hline & & & & & \\
\hline
\end{tabular}

It is noted from the above table that under CSR, PSUs have contributed $34 \%$ of the total target of toilet construction and target given to private corporate was only $1 \%$. On the other hand, $65 \%$ of the target has been taken up by the Government itself. With the abovementioned stakeholders in the SBA, the India Inc. has to play a major role in this mission of cleanliness. Though, private corporate contribution at the moment is only $1 \%$ while PSUs have significantly contributed to the toilet construction and cleanliness drive in the government schools. Therefore, the private corporate entity needs to shape itself to face the challenges in a most professional manner. Before making its commitment any business entity must define clearly on the following functions for its employees in particular and for the citizens in general.

\section{CASE STUDY}

\section{ONGC $^{5}$}

Eco-Friendly Toilets by Pravayan Evam Bhartiya Rural Tachnici Sansthan ${ }^{6}$ and Global Development Foundation and ONGC

ONGC has been mandated to construct 10,000 toilets on PAN India basis; it has engaged various NGOs in this respect. ONGC sanctioned initially 4 toilets and later on 5 more toilets in Raipur Block of Dehradun District to Pravayan Evam Rural Tachnici Sansthan (NGO), which has Global Development as knowledge partner in the execution of the project. The local community identified and provided the land, and society mandated to provide regular maintenance, upkeep, and sustainability. The difficulties encountered were related to the identification of land, corruption was a menace to handle for the release of a grant from ONGC.

\footnotetext{
${ }^{5}$ ONGC is Oil and Natural Gas Corporation Limited

${ }^{6}$ Pravayan Evam Bhartiya Rural Tachnici Sansthan is an NGO for the environment and rural development.
} 
Learning's from the case studies: The strong commitment is the mainstay for making this mission a success. The leakage and pilferage and corruptions are bound to be there, we need a very transparent and robust method and monitoring system for reducing the same.

Recommendations: The following are the key recommendations for SBA as suggested by Niti Ayog viii

- Behaviour Change Communication (BCC) Strategy It is recommended that funds for BCC may be increased uniformly, in both urban and rural areas, to about $25 \%$ of the total funds for the programme. Involve political and social/thought leaders, celebrities and media houses to spread the message of the importance of cleanliness and sanitation A database needs to be created which captures toilet usage by all households which will help in framing the strategy for the behavior change campaign and also enable to undertake mid-course corrections. A professional agency needs to be involved both at the Central and State level to design the strategy, mode of implementation and to monitor and evaluate the progress of the campaign as partnerships with UNICEF and WHO were crucial in the success of a campaign like the Pulse Polio campaign. The extensive media campaign in the form of electronic, web and print to be used for conveying messages and encouraging the people to pay for use of public toilets for their sustainability. The concept of three R's-Reduce, Reuse and Recycle needs to be strongly advocated. Cleaning occupations must be seen as a dignified work and widely respected.

- Education Strategy for Sustainable Swachh Bharat Mission. Inculcating sanitation practices in children by including a chapter in school curriculum from the first standard itself. In each school and college, a team of students may be formed which will be called the 'Swachhata Senani', to spread awareness about sanitation and cleanliness. Skill Development courses/ Diploma courses may be introduced in State ITIs and polytechnics/ colleges to train personnel in the field of solid and liquid waste management. Centres of Excellence may be set up in the institutes of higher learning to promote research in the specialized fields of sanitation and waste management. Specialized courses on Environmental Sciences, Public Health Engineering and Municipal Engineering with focus on sanitation and waste management may be introduced at undergraduate and postgraduate level. Joint Research Programmes with foreign universities/higher educational institutions would enhance knowledge and capacities to work on waste management technologies.

- Financial Requirements for the Swachh Bharat Mission: The funding pattern for this programme between the Centre and States may be in the ratio of 75:25, while for hilly States it may be kept at 90:10(Economic Times, 2015) ${ }^{7}$. The State Governments may consider setting up a Swachh Bharat Kosh on the lines of the Swachh Bharat Kosh constituted at the Central level. Donations to the Kosh should be eligible for $100 \%$ deduction under section $80 \mathrm{G}$ of the Income Tax Act. Each waste generator should pay for the waste generated based on polluter- pay principle. The charges for waste management may be collected along with property tax, water supply bills or electricity bills, as felt appropriate by the State Government $/ \mathrm{ULBs}^{8}$. A certain part of the CSR contributions by PSUs/Companies may be spent in the states where they are located. It is proposed that the first charge on the expenditure on 14th Finance Commission grants to Local Bodies shall be on the activities to be undertaken under Swachh Bharat Mission. The Government of India may advise the States accordingly.

\footnotetext{
${ }^{7}$ ET Bureau Oct 15, 2015, Centre may impose cess on petrol, diesel, telecom services to fund PM Narendra Modi's Swachh Bharat Abhiyan retrieved in October 2017

${ }^{8}$ ULB: Urban Local Bodies.
} 
- Robust Institutional Mechanisms: There should be a Mission at National and State level headed by the Prime Minister and Chief Minister.

\section{CONCLUSION}

This study demonstrates that for emerging economies like India, a partnership of Government and Corporates including PSUs for collaborative efforts to aggressively pursue the development goals can produce high impact in the society. This partnership is now endorsed by the government while it calls for financial and capacity support from the corporates for a development project like Swachh Bharat Abhiyan. The research supports the 'Chatterjee model' exhibiting the contribution of Corporates for development agenda. India's mandate for CSR spent has not only regulated the CSR spent amount for developmental and environmental issues but also brought forth the governance restructuring for corporates to have a CSR committee and CSR policy for greater transparency and hence making it an important material issue.

CSR's contribution towards the community, social and environmental issues will eventually impact the development index of the country. This research has identified four important issues for the contribution of corporates in development projects a) stakeholders' identification and their involvement in the implementation b) CSR contribution for development fund c) Utilization of corporates' strength under CSR umbrella d) Robust mechanism for monitoring and evaluation for greater impact.

This is preliminary and qualitative study yet an important research which explains the network of a government viz. local, state and national and corporates viz. private and PSUs for utilization of CSR as a tool for desirable changes: social and environmental in society. The section 135 has changed the development landscape in India and eventually will contribute to the national agenda in a big way. In future, CSR can be demonstrated as the clear quantitative contribution of corporates in the development of India. Government's transparency in bringing data to the public domain through its website is a way forward to corroborate the findings of this research that CSR is a potent tool for development. 


\section{REFERENCES}

Agwan, D. A. A., 2014. Corporate Social Responsibility: A gateway to Swachh Bharat Abhiyan. International Research Journal of Commerce and Law (IRJCL), pp. 13-15.

Alessia, D. \& Nigel, R., 2009. Toward an integrated model of leadership for corporate responsibility and sustainable development: a process model of corporate responsibility beyond management innovation. Corporate Governance: The International Journal of Business in Society, pp. 421-434.

Anon., 2017. SBA Challenges. [Online]

Available at: http://swachhbharat.mygov.in

[Accessed 02 Dec 2017].

Anon., 2018. CSR Portal. [Online]

Available at: http://www.csr.gov.in

[Accessed 6 Feb 2018].

Chatterjee, B. \& Nayan Mitra, 2017. CSR should contribute to the national agenda in emerging economies - the 'Chatterjee Model'. International Journal of Corporate Social Responsibility.

Chaudhary, K. \& Krishna, V. R., 2007. impact of CSR \& transformational leadership on brand community: an experimental study. Global Business Review, pp. 205-211. https://doi.org/10.1177/097215090700800202

Fara Azmat, R. S., 2009. Responsible Entrepreneurship in Developing Countries: Understanding the Realities and Complexities. Journal of Business Ethics.

Florez, R., 2013. 2013. Integrating Behavior Change and Hygiene in Public Policy: Four Key Dimensions. Water and sanitation program; guidance note. World Bank, Washington, DC. (C) World Bank. World Bank, Washington, DC.

Ghosh, S. K., 2016. Swachh Bharat Mission-A paradigm Shift in waste management \& cleanliness in India. procedia environment sciences, pp. 15-27.

Kumar, R., Murphy, D. F. \& Balsari, V., 2001. Understanding and Encouraging Corporate Responsibility in South Asia, s.1.: Tata Energy Research Institute.

Lawania, B. \& Kapoor, S., 2016. concept \& practice of strategic corporate social responsibility: special reference to CSR in ITC Limited. American International Journal of research in Humanities, Arts, and Social Sciences, pp. 83-87.

Mcgaw, N., 2005. Developing Leaders for a Sustainable Global Society. Strategic HR review, pp. 32-35. 
Moon, J., 2002. The Social Responsibility of Business and New Governance: Government and Opposition 37(3), .. doi:10.1111/1477-7053.00106, p. 385-408. https://doi.org/10.1111/1477-7053.00106

Patro, C. S. \& Raghunath, A. M. k., 2018. CSR: A Conscientious Take. In: Value Sharing for Sustainable and Inclusive Development. s.1. IGI Global, pp. 75-99. https://doi.org/10.4018/978-1-5225-3147-0.ch004

Raghunath, C. S. P. \&. M. K., 2017. Value Sharing for Sustainable and Inclusive Development, CSR: A conscientious take. USA: IGI Global.

Sanjay Pradhan, A. R., 2010. Corporate Social Responsibility in Rural Development. School of Doctoral Studies (European Union) Journal, pp. 139-147.

Sarkar, J. S. S., 2015. Corporate Social Responsibility in India - An Effort to Bridge the. Indira Gandhi Institute of Development Research, Mumbai.

Udayshankar, K., 2008. Corporate Social Responsibility \& Firm Size. Journal of business ethics, pp. 167-175. https://doi.org/10.1007/s10551-007-9609-8 


\section{Appendix 1}

Table: List of the abbreviations used in the research paper.

\begin{tabular}{|l|l|l|}
\hline S No. & Abbreviation & Explanation \\
\hline 1 & CAPEX & Capital Expenditure \\
\hline 2 & NGO & Non-Governmental Organisation \\
\hline 3 & ONGC & Oil and Natural Gas Corporation \\
\hline 4 & OPEX & Operational Expenditure \\
\hline 6 & PBT & Profit Before Tax \\
\hline 7 & PSU & Public Sector Undertaking \\
\hline 8 & RMSA & $\begin{array}{l}\text { Rashtriya Madhyamik Shiksha } \\
\text { Abhiyan }\end{array}$ \\
\hline 9 & SBA & Swacch Bharat Abhiyan \\
\hline 10 & SDGs & Sustainable Development Goals \\
\hline 11 & SSA & Sarva Shiksha Abhiyan \\
\hline 12 & WASH & Water, Sanitation and Hygiene \\
\hline
\end{tabular}

CSR Legislature: Section 135, the Companies Act 2013

\section{Corporate Social Responsibility}

(1) Every company having a net worth of rupees five hundred crore or more, or turnover of rupees one thousand crore or more or a net profit of rupees five crore or more

during any financial year shall constitute a Corporate Social Responsibility Committee of the

A board consisting of three or more directors, out of which at least one director shall be an independent director.

(2) The Board's report under sub-section (3) of section 134 shall disclose the the composition of the Corporate Social Responsibility Committee.

(3) The Corporate Social Responsibility Committee shall,-

(a) formulate and recommend to the Board, a Corporate Social Responsibility A policy which shall indicate the activities to be undertaken by the company as

specified in Schedule VII;

(b) recommend the amount of expenditure to be incurred on the activities referred

to in clause $(a)$; and

(c) monitor the Corporate Social Responsibility Policy of the company from time

to time.

(4) The Board of every company referred to in sub-section (1) shall,-

(a) after taking into account the recommendations made by the Corporate Social 
Responsibility Committee, approve the Corporate Social Responsibility Policy for the

company and disclose the contents of such Policy in its report and also place it on the

company's website, if any, in such manner as may be prescribed; and

(b) ensure that the activities as are included in Corporate Social Responsibility The policy of the company is undertaken by the company.

(5) The Board of every company referred to in sub-section (1), shall ensure that the the company spends, in every financial year, at least two percent. of the average net profits of

the company made during the three immediately preceding financial years, in pursuance of

its Corporate Social Responsibility Policy:

Provided that the company shall give preference to the local area and areas around it where it operates, for spending the amount earmarked for Corporate Social

Responsibility

activities:

Provided further that if the company fails to spend such amount, the Board shall, in its report made under clause $(o$ ) of sub-section (3) of section 134, specify the reasons for not

spending the amount.

Explanation.-For the purposes of this section "average net profit" shall be calculated in accordance with the provisions of section 198. 


\section{Appendix 2}

HISTORICAL PERSPECTIVE OF CSR LEGISLATION IN INDIA

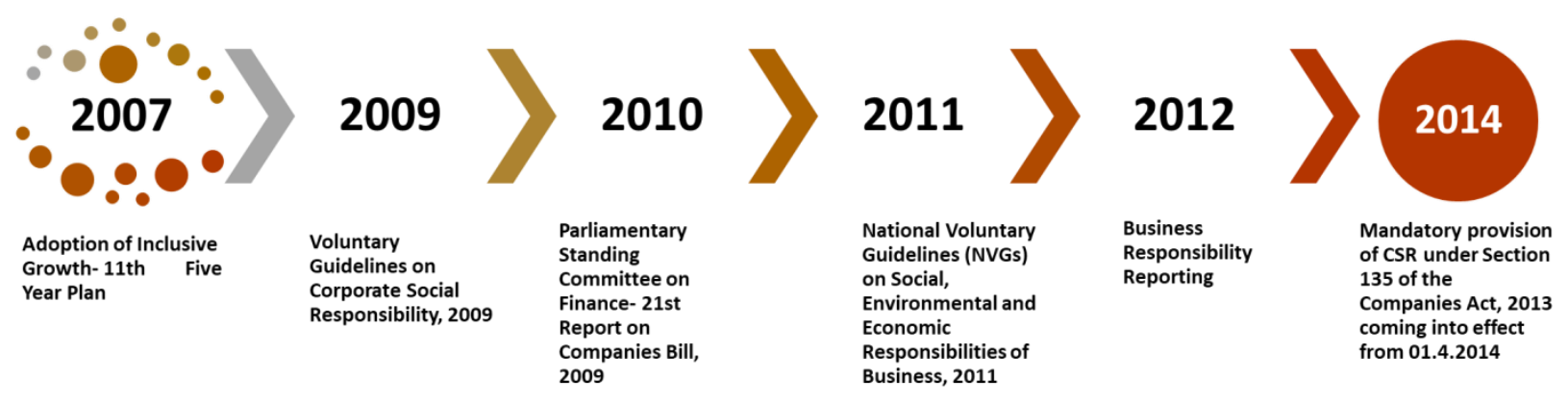

the importance of inclusive growth is widely recognized as an essential part of India's quest for development. It reiterates our firm commitment to include those sections of the society in the growth process, which had hitherto remained excluded from the mainstream of development. In line with this national endeavour, Corporate Social Responsibility (CSR) was conceived as an instrument for integrating social, environmental and human development concerns in the entire value chain of corporate business. Ministry of Corporate Affairs had issued 'Voluntary Guidelines on Corporate Social Responsibility, 2009' as a first step towards mainstreaming the concept of Business Responsibilities. This was further refined subsequently, as 'National Voluntary Guidelines on Social, Environmental and Economic Responsibilities of Business, 2011'.

The National Voluntary Guidelines (NVGs) on Social, Environmental and Economic Responsibilities of Business released by the Ministry of Corporate Affairs (MCA) in July 2011, is essentially a set of nine principles that offer Indian businesses an understanding and approach to inculcate responsible business conduct. These nine principles are:

i. conduct and govern themselves with ethics, transparency, and accountability.

ii. provide goods and services that are safe and that contribute to sustainability throughout their life cycle.

iii. promote the well-being of all employees.

iv. respect the interests of, and be responsive towards all stakeholders, especially those who are disadvantaged, vulnerable and marginalized.

v. respect and promote human rights.

vi. protect and make efforts to restore the environment.

vii. when engaged in influencing public and regulatory policy, they should do so in a responsible manner 
viii. support inclusive growth and equitable development

ix. engage with and provide value to their customers and consumers in a responsible manner.

These guidelines not being prescriptive in nature, nevertheless seek to guide Indian businesses to take into account Indian social and business realities and the global trends, while promoting their businesses.

Principle (viii) of the NVGs on 'inclusive growth and equitable development' focuses on encouraging business action on national development priorities, including community development initiatives and strategic CSR based on the shared value concept. This principle of NVG was subsequently translated into a mandatory provision of Corporate Social Responsibility (CSR) in Section 135 of the Companies Act 2013.

The 21st Report of the Parliamentary Standing Committee on Finance is one of the prime movers for bringing the CSR provisions within the statute. It was observed by the Standing Committee, that annual statutory disclosures on CSR required to be made by the companies under the Act would be a sufficient check on non-compliance. Section 135(4) of the Companies Act 2013 mandates every company qualifying under Section 135(1) to make a statutory disclosure of CSR in its Annual Report of the Board. Rule 9 of the Companies (Corporate Social Responsibility Policy), Rules, 2014 prescribes the format in which such disclosure is to be made. 
Lawania \& Kapoor | Leveraging Corporate Social Responsibility for the Advancement of Development Goals

\section{Appendix 3}

\section{Top Companies to factor their CSR to Swachh Bharat Abhivan by Amount Spent}

\begin{tabular}{|c|c|c|}
\hline S.No. & Company Name & Amount Spent(INR Lakh) \\
\hline 1 & $\underline{\text { Northern Coalfields Limited }}$ & $11,180.27$ \\
\hline 2 & Larsen And Toubro Limited & $6,000.00$ \\
\hline 3 & $\underline{\text { Gail (India) Limited }}$ & $3,173.41$ \\
\hline 4 & $\underline{\text { Pec Limited }}$ & $1,917.00$ \\
\hline 5 & $\underline{\text { Hindustan Unilever Limited }}$ & $1,847.00$ \\
\hline 6 & Hindustan Petroleum Corporation Limited & $1,581.68$ \\
\hline 7 & Ecgc Limited & $1,100.00$ \\
\hline 8 & Nuclear Power Corporation Of India Limited & $1,000.00$ \\
\hline 9 & Jsw Steel Limited & 426.00 \\
\hline 10 & $\underline{\text { Oil India Limited }}$ & 373.00 \\
\hline \multicolumn{2}{|c|}{ Total (in Lakh) INR } & $28,598.36$ \\
\hline
\end{tabular}


AABFJ | Volume 12, no. 2, 2018

iDonations to the "Swach Bharat Kosh", other than the sums spent for "Corporate Social Responsibility" under sub-section (5) of Section 135 of the Companies Act, 2013 are eligible for 100\% deduction under section 80G of the Income-tax Act, 1961. This is applicable to the assessment year 2015-16 and subsequent years

${ }^{i i}$ Swachh Bharat Kosh (SBK) has been set up to attract Corporate Social Responsibility (CSR) funds from Corporate Sector and contributions from individuals and philanthropists in response to the call given by Hon'ble Prime Minister on 15th August, 2014 to achieve the objective of Clean India (Swachh Bharat) by the year 2019.

iii Sarva Shiksha Abhiyan i.e. Education for All Movement), or SSA, is programme aimed at the universalization of elementary education as mandated by the 86th Amendment to the Constitution of India making free and compulsory education to children between the ages of 6 to 14.

${ }^{i v}$ Swachh Bharat Swachh Vidyalaya: an initiative by the Indian government to provide the facility of separate toilets to the boy and girl students in schools.

${ }^{\vee}$ Swachh Vidyalaya is the Indian government project of functional sanitation in schools.

${ }^{v i}$ SSA-Swacch Shiksha Abhiyan is the Indian government initiative for universalisation of elementary education.

vii The Rashtriya Madhyamik Shiksha Abhiyan (RMSA) scheme initiated in 2009, demonstrates the government's ambition for a secondary education system that can support India's growth and development.

viii Niti Ayog is planning commission of India and custodian of SDGs in India. 